Journal of Industrial Microbiology and Biotechnology

April 2009 ; Volume 36 (4) : Pages 599-604

http://dx.doi.org/10.1007/s10295-009-0529-8

(c) 2009 Springer. Part of Springer Science+Business

Media

The original publication is available at http://www.springerlink.com
Archimer, archive institutionnelle de l'ffremer http://www.ifremer.fr/docelec/

\title{
Investigations into the uptake of copper, iron and selenium by a highly sulphated bacterial exopolysaccharide isolated from microbial mats
}

\author{
Xavier Moppert ${ }^{1,}{ }^{*}$, Tinaïg Le Costaouec ${ }^{2}$, Gérard Raguenes ${ }^{2}$, Anthony Courtois ${ }^{2}$, Christelle Simon- \\ Colin $^{2}$, Philippe Crassous ${ }^{3}$, Bernard Costa ${ }^{1}$ and Jean Guezennec ${ }^{2}$
}

${ }^{1}$ CAIRAP Sarl, Centre d'Analyses Industrielles et de Recherche Appliquée pour le Pacifique, BP 1720, 98713, Papeete, Tahiti, French Polynesia

2 Institut Français de Recherche pour l'Exploitation de la Mer, BIOMAR/BMM, Centre de Brest, Plouzané, France

${ }^{3}$ Institut Français de Recherche pour l'Exploitation de la Mer, EEP/LEP, Centre de Brest, Plouzané, France

*: Corresponding author : X. Moppert, tél : (689) 541918 ; fax: (689) 4257 60, email address :

xmoppert@cairap.pf

\begin{abstract}
:
A bacterium isolated from microbial mats located on a polynesian atoll produced a high molecular weight $(3,000 \mathrm{kDa})$ and highly sulphated exopolysaccharide. Previous studies showed that the chemical structure of this EPS consisted of neutral sugars, uronic acids, and high proportions of acetate and sulphate groups. The copper- and iron-binding ability of the purified pre-treated native EPS was investigated. Results showed that this EPS had a very high affinity for both copper $\left(9.84 \mathrm{mmol} \mathrm{g}^{-1}\right.$ EPS) and ferrous iron $\left(6.9 \mathrm{mmol} \mathrm{g}^{-1}\right.$ EPS). Amazingly, this EPS did not show any affinity for either ferric ions or selenium salts. This finding is one of the first steps in assessing the biotechnological potential of this polysaccharide.
\end{abstract}

Keywords: Binding capacity - Copper - Iron - Microbial mats - Sulphated exopolysaccharide 


\section{Introduction}

Polysaccharides occur as important constituents of plant and microbial cell walls, either as storage polysaccharides or as biopolymers secreted by microorganisms which are known as exopolysaccharides (EPS). Bacterial polysaccharides possess a wide variety of properties that may not be found in the more traditional polymers of plant origin. Although they compete with polysaccharides from other sources, e.g. from algae (alginates, carrageenans) crustacea (chitin) or plants, their production is less subject to variability due to marine pollution, crop failure, or to climatic impact [11, 15, 24].

Due to their many interesting physical and chemical properties e.g. stabilizing, suspending, thickening, gelling, coagulating, film-forming, water retention capability, polysaccharides have found applications in many industrial sectors e.g. in detergents, textiles, adhesives, paper, paint, food and beverage industries, pharmaceuticals and cancer therapy, drug delivery, oil recovery and metal recovery in the mining industry and from industrial wastes $[3,5,12,22,25]$.

Heavy metals are known to be essential for almost all kind of living organisms but exceeding concentrations can lead to severe health problems. Biosorption of heavy and/or radioactive metals can be considered as an alternative technology able to compete with other conventional technologies such as chemical precipitation, electrolytic methods, adsorption on activated carbon, membrane process, ion exchange using different chelating resins and fibers [26, 27]. Bacterial exopolysaccharides (EPS) contain ionizable functional groups such as carboxyl, amine, sulphate, acetate, and hydroxyl groups which enable these polymers to bind heavy metals.

In French Polynesian atolls, microbial mats develop in water ponds exposed to salinity fluctuation and high solar irradiation. These microbial mats, which are called "kopara" by the inhabitants of Tuamotu archipelago, are mainly composed of cyanobacteria and eubacteria and contain high amounts of polysaccharides [16]. These exopolysaccharides preserve the integrity of the mat, prevent dessication and maintain cell hydrophobicity $[2,23]$. They also involved in the precipitation of carbonates [6,7]. Since 2001, this ecosystem has been screened for innovative biomolecules including novel microbial exopolysaccharides secreted under laboratory conditions by both bacteria and cyanobacteria [20, 21].

A marine bacterium (strain RA19), isolated from a microbial mat in Rangiroa atoll and belonging to the Paracoccus family produced an EPS under laboratory conditions. This strain, $P$. zeaxanthinifaciens. subsp. payriae, has been deposited in the Collection Nationale de Culture de Microorganismes (Institut Pasteur, Paris, France) as strain CNCM I-2926 [19]. The crude chemical composition included approximately $48 \%(\mathrm{w} / \mathrm{w})$ neutral sugars, $8 \%$ (w/w) uronic acids, $8 \%(w / w)$ of acetate and $27 \%(w / w)$ sulphate [19]. This study was conducted to investigate the ability of EPS produced by strain RA19 to bind heavy metals such as copper and iron as a first step in assessing the biotechnological potential of this EPS.

\section{Material and methods}

In November 2001, samples of « kopara » were collected from the different microbial mats located on the atoll of Rangiroa. Enrichment cultures were purified on Marine Agar 2216E (MA, Difco Laboratories, Detroit, USA). Strain RA19 was selected because of its ability to exhibit a swarming mucoid phenotype on Marine Agar 2216E supplemented with $30 \mathrm{~g} \mathrm{I}^{-1}$ of glucose along with a pigment further identified as pure all-trans-zeaxanthin [19]. 


\section{Growth conditions}

The optimal temperature for growth was between 30 and $35^{\circ} \mathrm{C}$, the optimal pH was between 6.5 and 7.5 and the optimal ionic strength was between 20 and $40 \mathrm{~g} \mathrm{I}^{-1}$ of NaCl. The doubling time, under optimal conditions, was 35 min [19].

\section{Isolation and purification of EPS}

Exopolysaccharide production was performed at $30^{\circ} \mathrm{C}$ in a 2-liter fermenter (New Brunswick, Toulouse, France) containing 1 liter of 2216E-glucose broth. A batch of culture medium was inoculated at $10 \%(\mathrm{v} / \mathrm{v})$ with a suspension of cells in exponential phase. The $\mathrm{pH}$ was adjusted and maintained at 7.6 by automatic addition of $\mathrm{NaOH} 1 \mathrm{~mol} \mathrm{I}^{-1}$. Foaming was avoided by addition of Pluronic-PE6100 oil (BASF, Levallois/Perret, France) at $0.1 \%(\mathrm{v} / \mathrm{v})$. The air flow was fixed at $30 \mathrm{I} \mathrm{h}^{-1}$ and the agitation rate from 200 to $400 \mathrm{rpm}$ in order to maintain the level of dissolved $\mathrm{O}_{2}$ around $25 \%$.

The water-soluble exopolysaccharide was recovered from the culture medium by high speed centrifugation $(20,000 \mathrm{~g}$ for 2 hours) after 4 days, then purified by ultracentrifugation against deionized water using a Pellicon-2 Mini Holder equipped with a Biomax 100K filter (Millipore Corporation, Bedford, MA, USA) and lyophilized prior to further analysis.

\section{Metal binding experiments}

Purified exopolymer was dissolved in milliQ water. Preliminary experiments were conducted with EPS concentrations up to $1 \mathrm{mg} \mathrm{ml}^{-1}$ according to protocols described by Loaec et al. $[13,14]$. Later this concentration was reduced to $0.1 \mathrm{mg} \mathrm{ml}^{-1}$ when problems in the methodology were attributed to the high viscosity of the polysaccharide in solution. Metals tested were copper, iron and selenium. Solutions of copper were prepared from anhydrous $\mathrm{Cu}\left(\mathrm{SO}_{4}\right)_{2}$. Solutions of ferrous and ferric iron were prepared from $\mathrm{FeSO}_{4}, 7 \mathrm{H}_{2} \mathrm{O}$ and $\mathrm{Fe}_{2} \mathrm{O}_{12} \mathrm{~S}_{3}, \mathrm{H}_{2} \mathrm{O}$ respectively while the assays for selenium were performed with $\mathrm{Na}_{2} \mathrm{SeO}_{3}$, $\mathrm{SeO}_{2}, \mathrm{H}_{2} \mathrm{SeO}_{3}$ and $\mathrm{Na}_{2} \mathrm{SeO}_{4}$.

Reaction solutions were prepared in duplicate by adding $40 \mathrm{ml}$ of EPS solution to a $250 \mathrm{ml}$ flask containing $10 \mathrm{ml}$ of metal solution for a final concentration of $0.1 \mathrm{mg} \mathrm{ml}^{-1}$ EPS and metals in the range of 10 to $1.000 \mathrm{mg} \mathrm{l}^{-1}$. The total sample volume was $50 \mathrm{ml}$. Samples were mixed thoroughly for $3 \mathrm{~h}$ at $200 \mathrm{rpm}$.

Metal uptake capacity was determined using the general equation [26]:

$$
q=\frac{(C i-C e q) \cdot V}{m}
$$

where Ceq is the final metal concentration and $\mathrm{Ci}$ the initial metal concentration in solution of volume $V$ and $m$ the mass of exopolysaccharide.

Appropriate blanks were examined throughout the sorption experiments to insure the absence of glassware sorption of metals and other potential side effects.

\section{Metal analyses}

After incubation, the $\mathrm{pH}$ of filtrates was reduced at 1.5 with concentred nitric acid and the metal concentration was determined by atomic absorption spectrometry or inductively coupled plasma spectrometry. All assays were run in triplicate. 


\section{FT-IR Spectroscopy}

Pellets for infrared analysis were obtained by grinding a mixture of $2 \mathrm{mg}$ polysaccharide with $200 \mathrm{mg}$ dry $\mathrm{KBr}$, followed by pressing the mixture into a $16 \mathrm{~mm}$ diameter mold. The Fourier transform-infrared (FT-IR) spectra were recorded on a Bruker Vector 22 instrument with a resolution of $4 \mathrm{~cm}^{-1}$ in the $4000-400 \mathrm{~cm}^{-1}$ region.

\section{Scanning electron microscopy}

Samples for scanning electron microscopy (SEM) analysis were glued to aluminium stubs, gold-sputtered, and examined using a Philips XL 30 operating at $30 \mathrm{kV}$. EDAX analysis (EDAX Edx 4i) was carried out on non-gold-coated specimens.

\section{Results and discussion}

\section{Chemical composition of EPS}

The exopolysaccharide (EPS) produced under laboratory conditions by strain RA19 is mainly composed of neutral sugars (48\%, w/w) while hexuronic acids only accounted for $8 \%(w / w)$ [19]. Acetate groups accounted for $8 \%(w / w)$ of the total EPS. But the major feature of this bacterial EPS was its high amount in sulphate $(27 \%$, w/w). Highly sulphated bacterial EPS are rare in nature making this exopolymer different from others. Sulphate groups play an important role in the biological activities of microbial polysaccharides. For several years there has been a growing interest in the recognition of biological activities of microbial polysaccharides [30]. The anticoagulant activity of some bacterial polymers have to be linked to the high sulfate content associated with specific chemical composition [17, 28].

\section{Heavy metal binding capacity}

Light cations including $\mathrm{K}, \mathrm{Na}, \mathrm{Mg}, \mathrm{Ca}$ are usually present in the crude exopolysaccharide due to both the medium culture and the extraction procedure. These metals were first eliminated by treatment with a cationic exchange column (Dowex 50X8) followed by an ultrafiltration. The biopolymer was then saturated with a single counter ion $\left(\mathrm{Li}^{+}\right)$to ensure an homogeneity of the cationic composition for all experiments. Complete elimination was achieved following this pre-treatment (Table 2).

The initial $\mathrm{pH}$ for copper sorption ranged from 4.5 to 5 and remained stable throughout the experiments. Initial pH for ferrous ions sorption was in the same range but a slight deposit of iron oxyhydroxyde $(\mathrm{FeOOH})$ was observed in the medium at the end of preliminary experiments. The $\mathrm{pH}$ was then adjusted to $\mathrm{pH} 3$ and all experiments were conducted under nitrogen to ensure the formation of such deposit.

Equilibrium sorption isotherms for copper and iron ( $\left.\mathrm{Fe}^{+11}\right)$ by EPS of $P$. zeaxanthinifaciens. subsp. payriae (RA19 EPS) are shown in figure 1. Sorption isotherms represent the equilibrium distribution of metal between the aqueous and the gel phase versus metal concentration. The sorption increases with the initial metal concentration as long as binding sites are not saturated. In that it can be hypothesized that metal accumulation by RA19 EPS is a chemical, equilibrated and saturable mechanism for both copper and iron (Fe $\left.{ }^{+11}\right)$.

The results are presented on both the basis of mass $(\mathrm{mg})$ uptake per gram EPS and on a molar basis (mmol g-1 EPS). Data are listed in Table 3 for copper and iron ( $\left.\mathrm{Fe}^{+\mathrm{ll}}\right)$. Copper uptake reached $625 \mathrm{mg} \mathrm{g}^{-1}$ EPS $\left(9.84 \mathrm{mmol} \mathrm{g}^{-1}\right.$ EPS) while iron $\left(\mathrm{Fe}^{+11}\right)$ uptake was lower with an uptake of $385 \mathrm{mg} \mathrm{g}^{-1}$ EPS (6.9 $\mathrm{mmol} \mathrm{g}^{-1}$ EPS).

Experiments were also conducted with ferric ions using $\mathrm{Fe}_{2} \mathrm{O}_{12} \mathrm{~S}_{3}, \mathrm{H}_{2} \mathrm{O}$ salts. Due to the formation of significant amount of $\mathrm{FeOOH}$, the $\mathrm{pH}$ of the solutions was lowered to 1.8. Under 
such conditions, no significant and reproducible metal uptake was observed for this polymer. The $\mathrm{pH}$ of the solution strongly affects the sorption capacity of this polymer. In strongly acidic solutions, protons compete with metal ions and are more available to protonate carboxyl groups then reducing the number of binding sites for ferric ions. In addition, degradation of the polymer occurred after 3 hours at such low $\mathrm{pH}$.

Experiments conducted with different selenium salts and under different $\mathrm{pH}$ conditions did not lead to any uptake of these ions by this EPS in its native state. Additional experiments will be conducted with partially depolymerised or deacetylated RA19 EPS in order to explain the absence of sorption by this biopolymer [8, 9].

These results have to be compared to other natural biosorbents. The value of $\mathrm{Q}$ derived from the Langmuir isotherm equation was up to $625 \mathrm{mg} \mathrm{g}^{-1}$ EPS and this value was much higher than the observed capacities or the estimated $Q$ values by other natural bacterial natural or modified exopolysaccharides and biomasses as well reported so far in the literature. Maximum copper uptake up to $323 \mathrm{mg} \mathrm{g}^{-1}$ EPS was reported for zooglane a polysaccharide produced by Zoogloea ramigera [18].

Iron uptake was also higher than for any bacterial polysaccharide reported in the literature. Maximum uptake was observed with the cell walls of Bacillus subtillis (201 $\mathrm{mg} \mathrm{g}^{-1}$ compared to $385 \mathrm{mg} \mathrm{g}^{-1}$ for RA19 EPS). The capacity of chitosan and crosslinked chitosan to adsorb ferrous ions did not exceed $64 \mathrm{mg} \mathrm{g}^{-1}$ [29], while Brierley and Brierley [4] related a Fe ${ }^{+11}$ retention capacity of $107 \mathrm{mg} \mathrm{g}^{-1}$ by bacterial biomass. Interestingly, up to initial concentrations of $500 \mathrm{mg} \mathrm{l}^{-1}$ and $300 \mathrm{mg} \mathrm{l}^{-1}$ of copper and ferrous iron respectively, the removal efficiency was near $100 \%(\mathrm{w} / \mathrm{w})$. For higher concentrations, significant decreased in the metal uptakes can be observed.

\section{Scanning electron microscopy}

Biosorption of both copper and iron salts by RA19 EPS induces change in the conformation of the polymer with the formation of microspheres up to $3 \mu \mathrm{m}$ diameter (Fig 2). Microanalysis performed on these microspheres indicated large concentrations of metal ions up to $70 \%$ $(w / w)$.

\section{FTIR study}

Infrared spectroscopy has proven to be a powerful tool for studying biological molecules and for obtaining information about metal-EPS binding. Figure 3 shows the FTIR spectra of Li treated RA19 EPS before and after binding experiments with either copper or iron (II). Analysis of the FTIR spectrum of the pre-treated polysaccharide showed intensive bands in the range of $3700-3200 \mathrm{~cm}^{-1}$ corresponding to the stretching band of $v \mathrm{OH}$ of polysaccharides. The FT-IR spectrum also exhibited an intense band at $1640 \mathrm{~cm}^{-1}$ along with an absorption peak at $1740 \mathrm{~cm}^{-1}$ corresponding to the stretching band of the free carboxyl double bond from the functional carboxylic groups present in this biopolymer. The doublet at $1230-1250 \mathrm{~cm}^{-1}$ corresponded to the presence of ester sulphate groups present in large proportion in this polymer.

Complexation with either copper or iron induced different shifts in the wavenumbers corresponding to specific vibrational modes of native exopolysaccharide. The most important differences in the vibrational spectra of the copper complexes seem to occur for the broad absorption peaks in the region of $3200-3700 \mathrm{~cm}^{-1}$ assigned to the existence of hydroxyl groups involved in the $\mathrm{H}$-bond network. Neither the copper nor the iron ions induced significant shifts in the vibration bands associated with carboxylic and sulphate groups as well.

The heavy metal binding capacity of polysaccharides are usually attributed to the high hydrophilicity of the polymer due to the presence of hydroxyl groups, the presence of functional and reactional groups (sulphate, acetamido, primary amino and ester groups) and 
the flexible structure of the polymer chains. RA19 EPS is characterized by high proportions of sulphate ( $27 \% \mathrm{w} / \mathrm{w}$ of the total sugar) and significant amounts of acetate groups (up to 8 $\%$ of the total sugar). It is widely accepted that carboxylic groups from either uronic acids or non sugar substituents are responsible for the metal binding capacity of EPS specifically in $\mathrm{pH}$ solutions ranging from 4 to 5 . However comparison between different bacterial EPS have clearly demonstrated that metal uptake capacities are not proportional to the concentration of uronic acids and carboxylic groups [13]. From our data, it can be hypothesized that hydroxyl groups are probably involved in the chelation of copper and iron by RA19 EPS as oxygen atoms from these groups could be weak donors [1].

The role of sulphate groups in the metal binding capacity of polysaccharides seems to be controversial $[14,10]$. Despite the very high content in sulphate of EPS RA19 neither copper ions nor ferrous ions seemed to affect the vibrational bands of sulphonate groups. Conversely sulphate groups are known to be involved in the overall uptake of trivalent ions such as ferric ions. In our experiments low $\mathrm{Fe}^{+\mathrm{III}}$ sorption was observed with this highly sulphated polysaccharide.

\section{Conclusion}

Human activities released in nature large amounts of toxic elements which can be harmful to human beings. Biosorbents and primarily exopolysaccharides can act as substitutes to other technologies. The EPS produced under laboratory conditions by the strain isolated from a microbial mat show very high binding capacity for both copper and iron salts. This finding could be the first step in the development of a low cost biosorbent used in its native state or as modified polysaccharide-based materials.

\section{Acknowledgments}

This study was financially supported by the CAIRAP SA (Arue, Tahiti). The authors would like to thank Research Ministry of the government of French Polynesian and specially Mrs Tea Frogier for her help in the organization of this research program.

\section{References}

1. Angyal SJ (1989) In: Tipson RS, Horton D (Eds.) Advances In Carbohydrate Chemistry and Biochemistry, vol. 47, Academic Press, Washington, DC, pp 1-43

2. Bar-Or Y, Shilo M (1987) Characterization of macromolecular flocculents produced by Phormidium sp. strain $\mathrm{J1}$ and by Anabaenopsis circularis PCC 6720. Appl Environ Microbiol 53:2226-30

3. Benedetti LM, Topp E, Stella VJ (1989) A novel drug delivery system: microspheres of hyaluronic acid derivatives. In: Crescenzi V, Dea ICM, Paoletti S, Stivala S, Sutherland IW (Eds.) Biomedical and Biotechnological Advances in industrial polysaccharides. Gordon and Breach, New York, pp 27-33

4. Brierley CL, Brierley JA (1993) Immobilization of biomass for industrial application of biosorption. In Torma AE, Apel ML, Brierley CL (ed) (vol II) Biohydrometallurgical Technologies Metal and Materials Society, Warr properties of an exopolysaccharide produced by Alteromonas infernus. Biochim Biophys Acta 1528:141-151

6. Defarge C, Trichet J, Coute A (1994) On the appearance of cyanobacterial calcification in modern stromatolites. Sediment Geol 94:1-19 
7. Defarge C, Trichet J, Maurin A, Hucher M (1994) Kopara in Polynesian atolls: Early stages of formation of calcareous stromatolites. Sediment Geol 89:9-23

8. Ferri T, Sangiorgio P (1999) Voltammetric study of the interaction between Se(IV) and dissolved organic matter in environmental aqueous matrices. Analytica Chimica Acta 385:337-43

9. Ferri T, Sangiorgio P (2001) Selenium speciation in waters: role of dissolved polysaccharides on the mobilization process. Annali di Chimica 91: 229-38

10. Figuera MM, Volesky B, Mathieu HJ (1999) Instrumental analysis of iron species biosorption by Sargassum biomass. Environ Sci Technol 33:1840-1846

11. Guezennec J (2002) Deep-sea hydrothermal vents: a new source of innovative bacterial exopolysaccharides of biotechnological interest? J Ind Microbiol Biotechnol 29:204-8

12. Gutnick D (1997) Engineering polysaccharides for biosorption of heavy at oil/water interfaces. Res. Microbiol. 148:519-521

13. Loaec M, Olier R, Guezennec J (1997) Uptake of lead, cadmiun and zinc by a novel bacterial exopolysaccharide. Water Res 31:1171-1179

14. Loaec M, Olier R, Guezennec J (1998) Chelating properties of bacterial exopolysaccharides from deep-sea hydrothermal vents. Carbohyd Polym 35:65-70

15. Mancuso Nichols CA, Guezennec J, Bowman JP (2005) Bacterial exopolysaccharides from extreme marine environments with special consideration of the southern ocean, sea ice, and deep-sea hydrothermal vents: a review. Mar Biotechnol 7:253-71

16. Mao Che L, Andrefouet S, Bothorel V, Guezennec M, Rougeaux H, Guezennec J, Deslandes E, Trichet J, Matheron R, Le Campion T, Payri C, Caumette P (2001) Physical, chemical, and microbiological characteristics of microbial mats (kopara) in the South Pacific atolls of French Polynesia. Can J Microbiol 47:994-1012

17. Nishino T, Nagumo T (1992) Anticoagulant and antithrombin activities of oversulfated fucans. Carbohydr Res 229:355-362

18. Norberg AB, Person H (1984) Accumulation of heavy-metal ions by Zoogloea ramigera. Biotechnol Bioeng 26:239-46

19. Raguenes G, Moppert X, Richert L, Ratiskol J, Payri C, Costa B, Guezennec J (2004) A novel exopolymer-producing bacterium, Paracoccus zeaxanthinifaciens subsp. payriae, isolated from a "kopara" mat located in Rangiroa, an atoll of French Polynesia. Curr Microbiol 49:145-51

20. Richert L, Golubic S, Guedes R, Ratiskol J, Payri C, Guezennec J (2005) Characterization of Exopolysaccharides Produced by Cyanobacteria Isolated from Polynesian Microbial Mats. Curr Microbiol 51:379-84

21. Rougeaux H, Guezennec M, Mao Che L, Payri C, Deslandes E, Guezennec J (2001) Microbial Communities and Exopolysaccharides from Polynesian Mats. Mar Biotechnol 3:181-87

22. Sandford PA, Baird J (1983) Industrial utilization of polysaccharides. In: Aspinall, G.O. (Eds) The polysaccharides. London, Academic Press, pp 411-490

23. Shilo M (1989) The unique characteristics of benthic cyanobacteria. Microbial Mats. In Cohen, Y., Rosenberg, E. (Eds) Washington, American Society for Microbiology, pp 207-13

24. Sutherland IW (1989) Bacterial exopolysaccharides: their nature and production. Antibiot Chemother 42:50-55

25. Sutherland IW (1994) Structure-function relationships in microbial exopolysaccharides. Biotechnol Adv 12:393-448

26. Volesky B (1990) Removal and recovery of heavy metals by biosorption. In Volesky, B. (Eds) Biosorption of Heavy Metals. Washington, Boca Raton FL CRC Press, pp 7-44

27. Volesky B, Holan ZR (1995). Biosorption of heavy metals. Biotechnol Prog 11:235-250

28. Volpi N, Sandri I, Venturelli T (1995) Activity of chrondroitin ABC lyase and hyaluronidase on free-radical degraded chondroitin sulfate. Carbohydr Res 279:193-200

29. Wan Ngah WS, Kamari A, Koay YJ (2004) Equilibrium and kinetics studies of adsorption of copper (II) on chitosan and chitosan/PVA beads. Int J Biol Macromol 34:155-161

30. Weiner R, Langille S, Quintero E (1995) Structure, function and immunochemistry of bacterial exopolysaccharides. J Ind Microbiol 15, 339-346endale pp: 35-44 
5. Colliec-Jouault S, Chevolot L, Helley D, Ratiskol J, Bros A, Sinquin C, Roger O, Fisher AM (2001) Characterization, chemical modifications and in-vitro anticoagulant

\section{Tables}

Table 1 Percentage of light cations in EPS produced by strain RA19 ( $P$. zeaxanthinifaciens subsp. payriae) $(\%, w / w)$

\begin{tabular}{|l|l|l|l|l|}
\hline EPS RA19 & $\mathrm{Na}^{+}$ & $\mathrm{K}^{+}$ & $\mathrm{Ca}^{2+}$ & $\mathrm{Mg}^{2+}$ \\
\hline Native state & 3.73 & 0.48 & 1.88 & 1.27 \\
\hline Pre-treatment & $<0.01$ & $<0.01$ & $<0.01$ & $<0.01$ \\
\hline
\end{tabular}

\section{Figures}

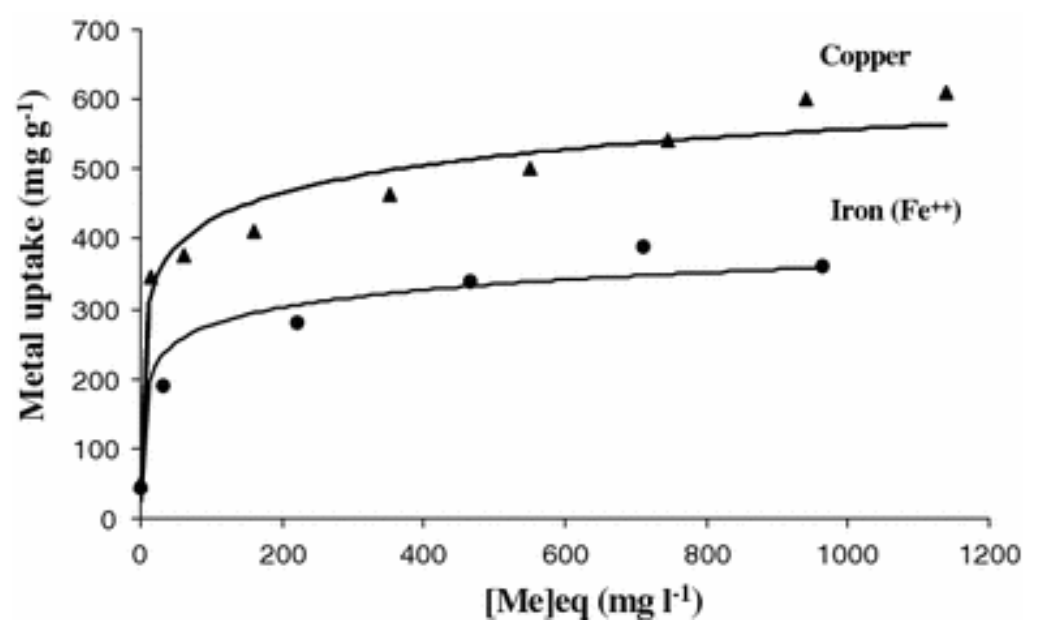

Fig. 1 Equilibrium sorption isotherms of copper and iron $\left(\mathrm{Fe}^{+11}\right)$ by RA19 EPS ( $3 \mathrm{~h}$, room temperature). Standard deviations of triplicate measurements are smaller than symbol diameters. 


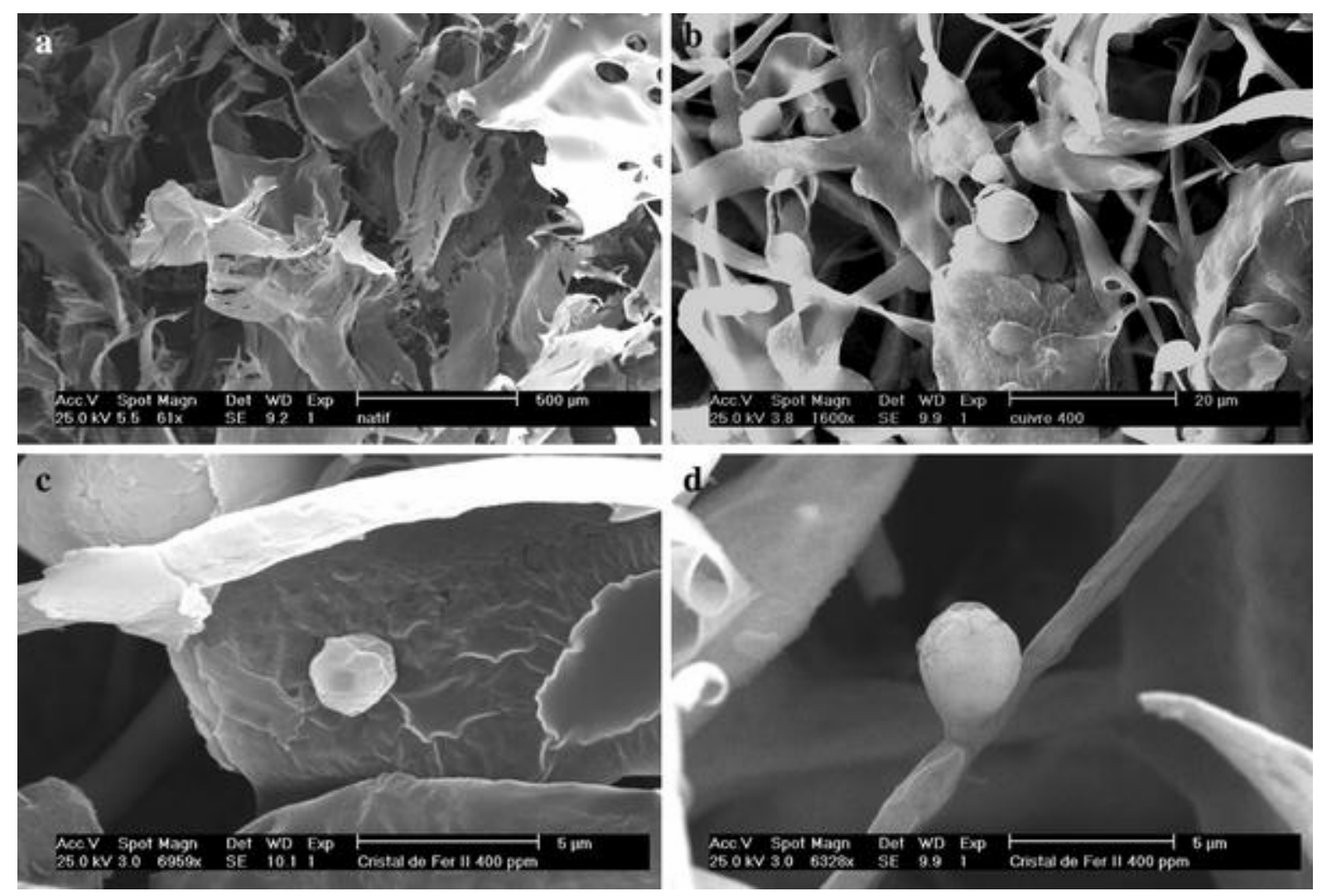

Fig. 2 Scanning electronic microscopy photography of a native RA19 EPS; b RA19 EPS-Cu; c, d RA19 EPS-Fe

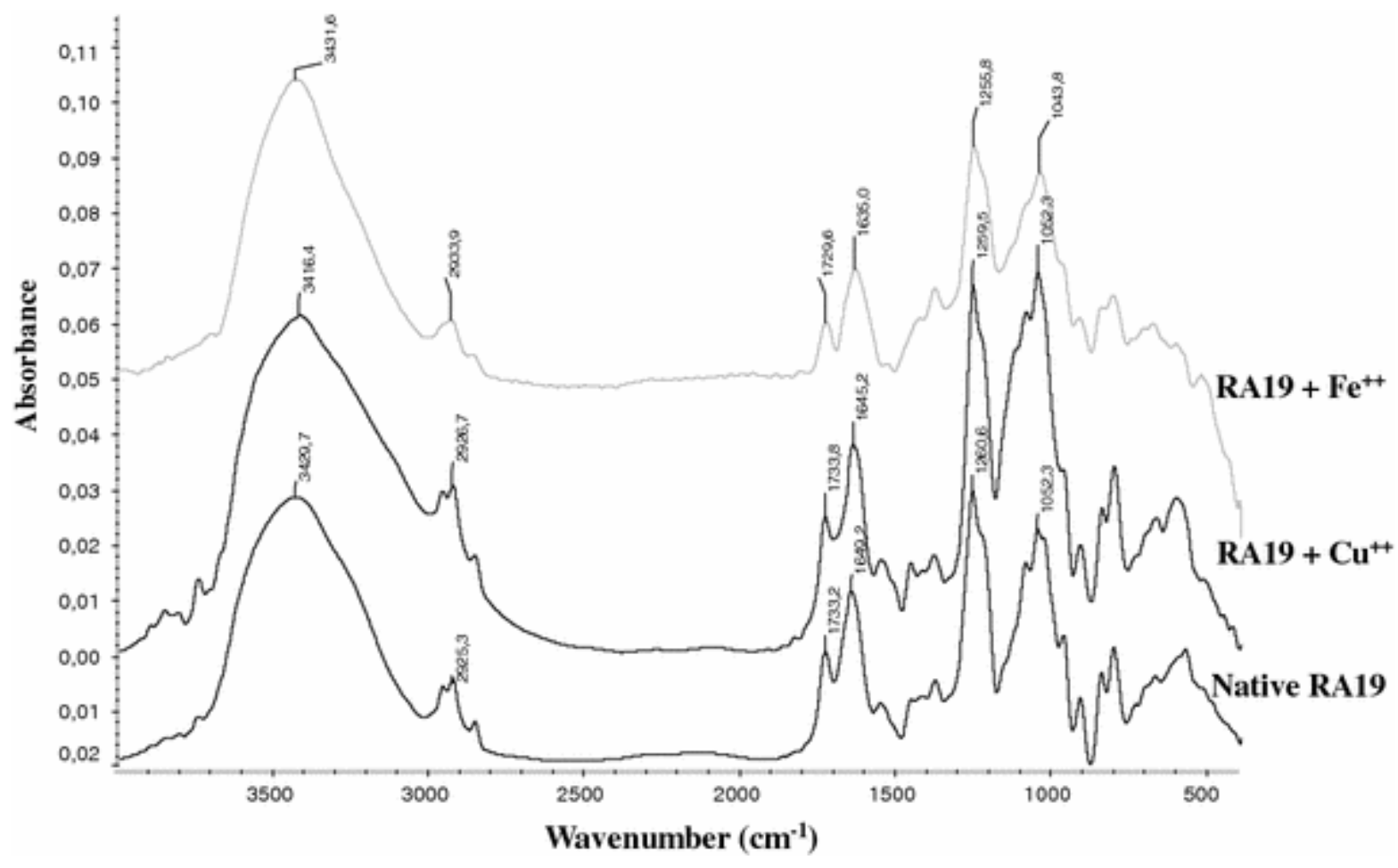

Fig. 3 FT-IR spectra of RA19 EPS before and after copper or iron $\left(\mathrm{Fe}^{+11}\right)$ biosorption 